\title{
Bank Solvency and Funding Cost
}




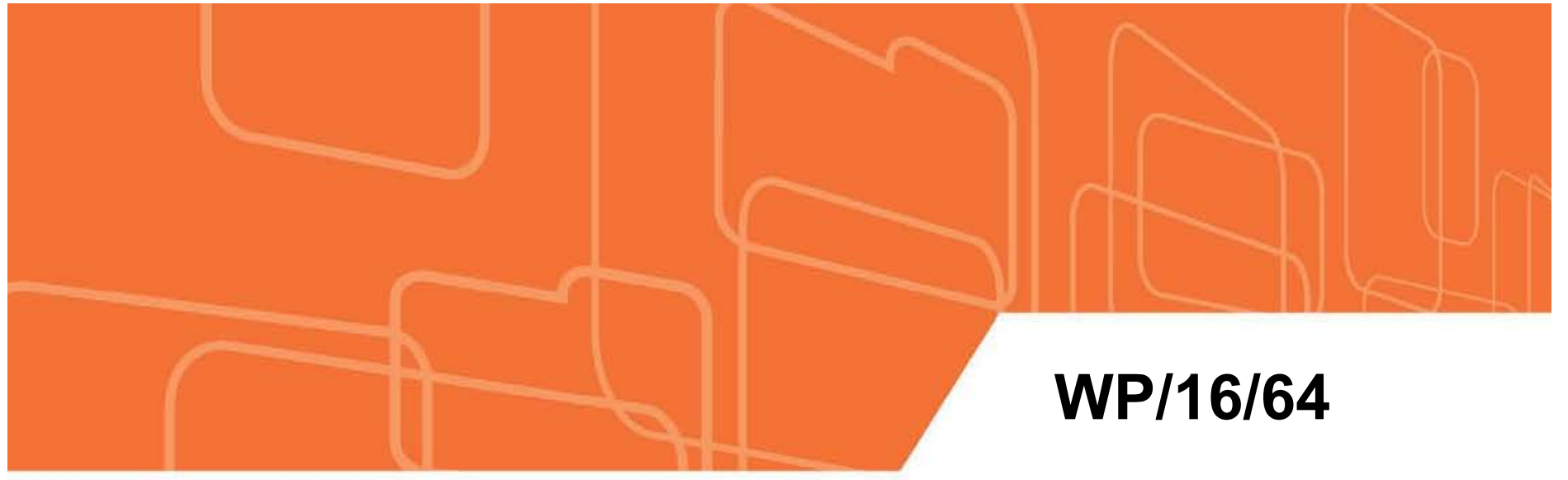

\section{IMF Working Paper}

\section{Bank Solvency and Funding Cost}

by Christoph Aymanns, Carlos Caceres, Christina Daniel, and Liliana Schumacher 


\title{
IMF Working Paper
}

Monetary and Capital Markets Department

Bank Solvency and Funding Cost

\section{Prepared by Christoph Aymanns, Carlos Caceres, Christina Daniel, and Liliana Schumacher*}

Authorized for distribution by Udaibir S. Das

March 2016

IMF Working Papers describe research in progress by the author(s) and are published to elicit comments and to encourage debate. The views expressed in IMF Working Papers are those of the author(s) and do not necessarily represent the views of the IMF, its Executive Board, or IMF management.

\begin{abstract}
Understanding the interaction between bank solvency and funding cost is a crucial prerequisite for stress-testing. In this paper we study the sensitivity of bank funding cost to solvency measures while controlling for various other measures of bank fundamentals. The analysis includes two measures of bank funding cost: (a) average funding cost and (b) interbank funding cost as a proxy of wholesale funding cost. The main findings are: (1) Solvency is negatively and significantly related to measures of funding cost, but the effect is small in magnitude. (2) On average, the relationship is stronger for interbank funding cost than for average funding cost. (3) During periods of stress interbank funding cost is more sensitive to solvency than in normal times. Finally, (4) the relationship between funding cost and solvency appears to be non-linear, with higher sensitivity of funding cost at lower levels of solvency.

JEL Classification Numbers: C50, G00, G10, G21.
\end{abstract}

Keywords: Solvency, funding cost, bank fundamentals, stress testing.

Author's E-Mail Address: aymanns@maths.ox.ac.uk, ccaceres@imf.org, cdaniel@imf.org, and lschumacher@imf.org

\footnotetext{
* Without any implication, the authors would like to thank Alberto Behar, Mario Catalan, Dimitri Demekas, Dale Gray, Pierpaolo Grippa, Tigran Poghosyan, Jean Portier, Miguel Savastano, Miguel Segoviano, and Laura Valderrama, as well as participants at the September 2014 Monetary and Capital Markets seminar for their insightful comments and suggestions.
} 
A. Datasets

B. Variable Construction

C. Data Cleaning-U.S. Banks

III. ESTIMATION METHODOLOGY AND MAIN RESULTS: U.S. BANKS

A. Estimation Methodology

B. Main Results

IV. EXTENSION TO A GLOBAL BANK DATASET

V. SUMMARY AND CONCLUSIONS

REFERENCES

\section{FIGURES}

1. Distribution of Wholesale Funding Cost (proxied by Interbank Funding Cost) __ 25

2. Estimated Coefficients of the Solvency Measure 26

3. Estimated Coefficients and p-values of Coefficients of the Solvency Measure

4. Goodness of Fit (as measured by the Pseudo R-squared)

$\underline{28}$

\section{TABLES}

1. Pairwise Correlations of Funding Cost Variables 17

2. Summary Statistics for FDIC Dataset

3. Estimates of Logit Model Linking Measures of Bank Fundamentals

4. Estimation Results for Linear Panel Estimation

5. Estimation Results for Piecewise Panel Estimation

6. Estimation Results for Panel Estimation

7. Summary Statistics for SNL Dataset

8. Estimation Results for Linear Panel Estimation

24




\section{INTRODUCTION}

A bank's access to and cost of unsecured funding depends on its creditors' assessment of the counterparty risk associated with the loan contract. Among other factors, the perception of counterparty risk is driven by measures of the bank's fundamentals such as solvency and asset quality. This dependence creates an interaction between the state of a bank's assets and its access to funding. In other words, it establishes a link between asset risk and funding risk. Theoretical models have shown that the interaction between these different types of risk can cause significant financial fragility, see for example Caccioli et al. (2014) or Brunnermeier and Pedersen (2009).

The literature on the role of "market discipline" asks related questions. Markets can discipline banks by affecting their funding costs or their equity prices. A number of studies in the literature focus on depositor-induced discipline. For instance, Berger and Turk-Ariss (2014) assess the presence of depositor discipline effects in the wake of the global financial crisis. Likewise, Ioannidou and Dreu (2006) study the impact of explicit deposit insurance on market discipline, whereas Maechler and McDill (2006) analyze banks' dynamic response to depositor discipline.

A good understanding of the interaction between solvency and funding risk is crucial for the assessment of a bank's fragility. This is particularly relevant for stress tests to determine a bank's susceptibility to exogenous shocks. Typically an exogenous shock is derived from a macro-economic model that produces various growth scenarios. A particular growth scenario then determines the bank's pay-off on its investments and thereby the value of its assets. Thus, an adverse growth scenario can lead to a deterioration of the bank's solvency position. Once the bank's solvency has deteriorated, providers of unsecured funding are likely to respond by raising the interest rate charge on these loans. As a result, the bank not only has to cope with deteriorating asset quality and reduced income, but also faces a higher cost of funding. In such a scenario, the bank's net interest margin is squeezed on both ends. This can have two effects. First, a decline in the bank's net interest margin impairs its ability to recover from the initial shock. This will make the effects of the adverse shock more persistent. Second, and more importantly, an increase in funding cost can render the entire bank or parts of its business (i.e. certain asset classes) unprofitable. A destabilizing feedback may ensue: the losses triggered by the increase in funding cost may lead to a further deterioration of solvency which in turn raises funding cost even higher. In order to restore capitalization to adequate levels the bank is likely to sell off unprofitable assets. If this occurs in a sufficiently large scale, the resulting price impact can lead to contagion across the financial system affecting the solvency position of banks holding assets similar as those held by the stressed bank. As a result of these feedback and knock-on effects an initial shock to a bank can be greatly amplified.

This paper is related to the literature on bank funding cost, and its effect on different financial risks. Previous studies on bank funding costs have found a negative relationship between measures of solvency and funding cost. Typically such studies use market-based 
proxies for funding cost. For example, Babihuga and Spaltro (2014) show that, within the context of an error correction model, the credit default swap (CDS) spreads of 25 large banks from the United States (US), United Kingdom (UK), Euro Area (EA), and Scandinavia are negatively related to the level of a bank's total capital ratio in the long run. This paper confirms this initial finding and extends it to a larger sample of banks; it also shows its validity beyond market-based measures of funding cost.

Measures of capital and funding cost can also be backed out from observed equity volatility, for instance, using Contingent Claims Analysis (CCA). Gray (2015) outlines how CCA can be used to compute credit spreads from default probabilities and ratings. Combing implied credit spreads with an implied capital ratio yields a strong non-linear relationship between funding cost and solvency, where lower levels of solvency increases funding cost. This approach has already been applied to a number of stress tests. A similar approach relating a bank's implied rating with its funding cost has been proposed by Schmieder et al (2012), which incorporate the interaction between funding cost and solvency in a framework for system-wide liquidity stress testing.

Hybrid models using both ratings and balance sheet data have also been used to assess the interaction between bank funding cost and its solvency (see for example Aikman et al. (2009)). In the Bank of England's Risk Assessment Model for Systemic Institutions (RAMSI), the impact of fundamentals on a bank's rating is estimated using an ordered profit model. A shock to fundamentals can then be translated directly to a shock to the bank's rating. A rating shock is then translated into a funding cost shock via Merrill Lynch's indices of UK sterling bond spreads.

This paper is also related to the literature on the interaction between different types of financial risk. In times of financial stress, funding risk and market risk tend to amplify each other. When borrowers rely on short term debt, lenders may be unwilling to roll-over debt if the quality of the borrower's assets decreases. The borrower may therefore be forced to liquidate part of its assets at fire sale prices. This mechanism has been illustrated in a theoretical model by Brunnermeier and Pedersen (2009). In this paper we study how sensitive lenders are to shocks to the capital and other fundamentals of borrowers. The magnitude of this sensitivity is crucial in understanding the strength of the amplification mechanism between funding and other sources of risk.

We use data for U.S. and global banks to improve our understanding of the link between solvency and funding cost. In particular, we perform a panel estimation to assess the effects on balance sheet based measures of average and wholesale funding cost to changes in measures of bank fundamentals. ${ }^{1}$ In order to capture a wide range of indicators of bank fundamentals while avoiding the problem of co-linearity of regressors, we construct measures of bank fundamentals by aggregating different indicators into CAMELS-type measures using Principal Component Analysis (PCA). We restrict our analysis to balance

\footnotetext{
${ }^{1}$ We proxy wholesale funding cost by the bank's interbank funding cost.
} 
sheet data for two reasons. Firstly, this allows us to undertake the analysis using a very large sample of banks both in cross section and over time. ${ }^{2}$ To our knowledge this is the first study of this type with such a comprehensive dataset. Secondly, the use of balance sheet data makes our findings directly applicable to stress tests that themselves rely on balance sheet data. While the core of our analysis focused on the linear sensitivity of funding cost to solvency and how it changes over time, we also make an attempt at characterizing the nonlinear aspects of this relationship.

The remainder of the paper is structured as follows. Section II introduces the U.S. dataset and focuses on the construction of measures relating to bank fundamentals. Section III presents the estimation model and the main findings for U.S. banks. Section IV presents further evidence from a global bank dataset. Section V interprets the results and concludes.

\section{Data And Construction of the Main Variables}

\section{A. Datasets}

Our analysis of the link between bank funding cost and solvency is based on balance sheet data. A bank's wholesale funding cost, i.e. the interest rates charged by the bank's creditors, depends, among other factors, on the lenders' perception of the bank's probability of distress. ${ }^{3}$ That is, lenders assess the bank's default probability and adjust the interest rate they charge accordingly. In principle, there are two ways to access data on interest rates and default probabilities of any given bank.

First, interest rates and default probabilities can be extracted from market data. A popular proxy for a bank's marginal wholesale funding cost are CDS spreads (see for example Babihuga and Spaltro (2014)). An alternative proxy of bank marginal wholesale funding cost is bank bond prices. However, it is harder to gain access to the relevant data for such proxy. Furthermore, a bank's default probability is often implied from the bank's CDS spreads, see for example, Gray (2015).

A second source of data on bank funding cost and their default probability are bank balance sheet reports. Data on a bank's interest expense on debts allows for the construction of proxies of wholesale funding cost. In addition, several balance sheet indicators (such as nonperforming loans or capital ratios) can be used to construct measures of a bank's default probability, see for example Cole and $\mathrm{Wu}(2009)$.

Market data is usually available at a much higher frequency than balance sheet reports and generally offers better proxies of a bank's marginal wholesale funding cost. However, market data is only available for a rather small subset of banks while balance sheet reports are

\footnotetext{
${ }^{2}$ Our sample size for the U.S. is approximately 10,000 banks over 21 years; for the global dataset, the sample contains 2,700 banks over 10 years.

${ }^{3}$ While retail depositors may still be sensitive to the bank's default probability, deposit insurance schemes will make them much less sensitive than wholesale investors who are not covered by deposit insurance.
} 
available for a very large sample of both U.S. and global banks. Furthermore, the temporal variation of bank funding cost is driven to a large extent by common factors such as the central bank policy rate, market volatility or global risk aversion. Therefore, the dependency between perceived default probability and bank funding cost has to be identified by exploiting the cross-sectional rather than the temporal dimension. These considerations motivate our choice of balance sheet data over market data.

We use balance sheet reports from two datasets of U.S. and global banks. Our primary analysis is based on the Federal Deposit Insurance Corporation (FDIC) Call Report dataset that contains quarterly data for approximately 10,000 U.S. banks over a period of 21 years ranging from 1993 to 2013 . We supplement this analysis with a global dataset from SNL Financial with yearly data for approximately 2,700 banks from 80 different countries. In order to make the FDIC data compatible with the SNL dataset we average the FDIC data over four quarters to obtain annual averages. The core of our analysis is centered on the fairly comprehensive sample of U.S. banks, and thus we focus on the FDIC dataset in the next sections. We will briefly discuss the SNL dataset subsequently in section IV.

\section{B. Variable Construction}

Our analysis takes the perspective of a "fundamentalist investor." In a simple model, a fundamentalist investor observes measures of bank fundamentals in order to infer the bank's probability of default and then sets the interest rate it charges to the bank.

\section{Measures of funding cost}

We construct proxies for average and wholesale funding cost. The average funding cost will include payments made to all the bank's creditors (i.e., both retail and wholesale depositors) while wholesale bank funding cost will only include a subset of wholesale lenders. The distinction between average and wholesale funding costs allows us to disentangle the response of wholesale and retail depositors to shocks to bank fundamentals.

Average funding cost: We define the average funding cost as the ratio of total interest expense to total liabilities during the reporting period. For the FDIC data, this corresponds to the ratio of quarterly total interest expense to total liabilities during that quarter. The annualized ratio is then averaged over the corresponding year to yield a variable with yearly frequency.

The average funding cost captures all the bank's liabilities, and is dominated by retail deposits for most banks. We therefore expect the sensitivity of this funding cost measure to changes in bank fundamentals to be relatively small. Nevertheless, it is important to estimate this sensitivity for two reasons. First, it provides a baseline for comparison for the sensitivity of wholesale funding cost to changes in bank fundamentals. Second, it allows an estimate of the relevance of a realistic shock to fundamentals for the operation of a bank as a whole. 
We use total liabilities rather than total interest-bearing liabilities for data availability reasons, given that none of the datasets used in this analysis reports total interest-bearing liabilities. However, evidence from other global banking datasets (in particular, Bankscope) shows that these two measures are very similar with a highly significant correlation coefficient of approximately $0.99 .{ }^{4}$ Thus, while the numerical value of the computed average funding cost may be biased downwards, the estimated regression coefficient will still be accurate due to the strong co-movement of total liabilities and total interest bearing liabilities.

Wholesale funding cost: We proxy wholesale funding cost by a bank's interbank funding cost, which we define as the ratio of interest rate expense on federal funds and repos purchased to the total stock of federal funds and repos purchased during the reporting period. Again, we first compute the interbank funding cost on a quarterly basis and then average over the corresponding year to obtain yearly data. This measure of funding cost includes secured and unsecured loans, as well as overnight and term loans, and represents on average about 9 percent of U.S. bank's total liabilities. While a breakdown of this measure along the maturity and collateral dimensions is not available from the FDIC, studies have shown that unsecured federal funds represent 70 percent of the liabilities summarized in this measure; see for example, Afonso et al. (2011). Furthermore, most of the unsecured federal funds are overnight with estimations of the term segment ranging from 10 percent to 50 percent. Since the majority of the liabilities captured by our measure of wholesale funding cost are unsecured, we expect that "active lenders", i.e., banks, are sensitive to the fundamentals of the borrower and charge varying risk premia. However, since most of the captured liabilities are also of very short maturity, any effect detected with our measure of wholesale funding cost is likely to underestimate the true sensitivity of the cost of long-maturity wholesale funding.

Table 1 shows that both proxies of funding cost are significantly correlated with the U.S. TBill rate, the central bank policy rate (i.e., Fed funds rate target), and the VIX. This again reinforces the need for a large cross-sectional sample in order to identify a relationship between funding cost and bank fundamentals.

\section{Measures of bank fundamentals}

We measure the quality of bank fundamentals via its solvency, asset quality, liquidity and profitability. These are the variables a fundamentalist investor will use to assess a bank's default probability. All these measures of bank fundamentals appear to be linked to the default probability of a bank. In general, one would expect that the higher a bank scores in any of these dimensions, the lower its default probability. We explicitly check this conjecture later. Since bank capital ratios, such as the Tier 1 capital ratio, are subject to regulation and of particular relevance during bank stress tests, we will focus on the impact of changes to

\footnotetext{
${ }^{4}$ This might underestimate the level of funding cost, but not necessarily the variation in it. Thus, this is not likely to affect in any meaningful way most of the estimation results presented hereafter.
} 
these solvency measures on bank funding cost throughout this paper while controlling for all other measures of bank fundamentals.

We construct a measure for each of the four fundamental dimensions by aggregating a number of balance sheet variables that correspond to a particular dimension via Principal Component Analysis (PCA). Suppose we use balance sheet variables $\mathrm{V}_{1 \mathrm{i}}$ to $\mathrm{V}_{\mathrm{Ni}}$ to construct a measure of liquidity, where the index $i$ labels the $i$-th bank in the dataset. We then compute the principal components of the distribution of $\mathrm{N}$ dimensional data points for the entire dataset, i.e., over all banks $i$. The value of the corresponding liquidity measure for a particular bank $j$ is then obtained from the projection of $\left(\mathrm{V}_{1 \mathrm{j}}, \mathrm{V}_{2 \mathrm{j}}, \ldots, \mathrm{V}_{\mathrm{Nj}}\right)$ onto the first principal component. This method allows us to include the contribution of a larger number of indicators of bank fundamentals while avoiding co-linearity among the regressors. In particular, for the FDIC dataset we choose the following constituent variables $\left(\mathrm{V}_{1 \mathrm{i}}\right.$ in the above example) for the four dimensions of bank fundamentals:

- Solvency $\left(S O_{i t}\right.$ ): Tier 1 capital ratio, total regulatory capital ratio, leverage ratio.

- Asset quality $\left(A Q_{i t}\right):{ }^{5}$ Net-charge offs to loans, credit loss provisions to net charge offs, earnings coverage of net-charge offs, noncurrent loans to total loans. ${ }^{6}$

- Liquidity ( $L I_{i t}$ ): liquid assets to total assets, volatile liabilities to total liabilities, ${ }^{7}$ deposits to assets.

- Profitability ( $P R_{i t}$ ): Return on equity (ROE), return on assets (ROA), net interest margin.

Note that we proxy bank solvency with measures of capital adequacy or capitalization. This is because capital adequacy is an important predictor of bank solvency and default. We check the relevance explicitly by estimating the effect of this solvency measure on a bank's probability of default. We compute explicitly the correlations within a dimension of fundamental value and among the constructed measures of bank fundamentals (see Table 1). Constituent variables for a particular measure are typically highly correlated, while the constructed measures are not very correlated.

\footnotetext{
${ }^{5}$ Some of the constituent variables for asset quality are negatively associated with asset quality, i.e. the higher their value, the lower a bank's asset quality. We therefore take the convention that lower values of asset quality are preferred. The underlying variables are thus multiplied by "-1" within this component.

${ }^{6}$ Assets past due 90 days or more, plus assets placed in nonaccrual status.

${ }^{7}$ Federal funds purchased and securities sold under agreements to repurchase, demand notes issued to the U.S. Treasury and other borrowed money, time deposits over $\$ 250,000$ held in domestic offices, foreign office deposits, trading liabilities less trading liabilities revaluation losses on interest rate, foreign exchange rate, and other commodity and equity contracts.
} 


\section{Bank and temporal controls}

Two additional factors, not captured by our four measures of bank fundamentals, are likely to affect the bank's funding cost: (1) relative size ( $\left.R E_{i t}\right)$ and (2) the fraction of insured deposits $\left(F I_{i t}\right)$. We define the relative size of the bank as the log of the ratio of the bank's total assets divided by the total assets in the sample. One would expect that larger banks are able to achieve lower funding costs due to their market power and access to a larger set of potential lenders. Similarly, a bank with a larger fraction of insured deposits should have lower funding costs due to a decreased probability of default. Furthermore, we control for temporal effects either by including time dummies or time series of the variables such as VIX, U.S. T-bill rates and GDP growth rate. Since our focus is on the relationship between bank fundamentals and funding cost we will choose time dummies in most cases.

\section{Data Cleaning-U.S. Banks}

We exclude outliers and invalid observations from our analysis. Observations are dropped from the dataset when they meet any of the following conditions: Funding cost in excess of 30 percent per quarter, ROE (ROA) larger than 50 percent ( 5 percent) or smaller than 50 percent (-5 percent), net interest margin larger than 10 percent, any variable with an invalid value (e.g., ratio larger than one or wrong sign). Table 2 summarizes the final dataset.

\section{Estimation Methodology and Main Results: U.S. Banks}

\section{A. Estimation Methodology}

To evaluate the relation between our measures of bank fundamentals and bank default probability, we estimate a simple logit model. We obtain data on bank default from the FDIC bank default dataset.

We then proceed to estimate linear and nonlinear models relating bank funding costs to bank fundamentals. For the FDIC datasets, we estimate a linear model on the entire panel data. We repeat the same estimation for each year in the sample. These annual estimations allow us to investigate whether the sensitivity of investors to shocks to fundamentals varies over time. However, a simple linear model is not likely to be useful to capture the response of an investor to changes in bank fundamentals. Investors are likely to penalize more the same absolute deterioration in bank fundamentals when a bank is already in trouble than if it is not. We investigate this conjecture by estimating two types of nonlinear models on the entire panel. First, we estimate a simple piecewise linear regression with a variable threshold on the solvency measure. Second, we apply a two-parameter non-linear transformation to the solvency measure and re-estimate the model on the entire panel dataset for different values of the transformation parameters.

\section{Bank fundamentals and bank default}

The dependent variable in the logit model estimated to check whether our measures of bank fundamentals are reasonably related to bank default is defined as follows: 


$$
F A I L_{i t}=\left\{\begin{array}{l}
1, \text { if bank i failed at time } \mathrm{t}+1 \\
0, \text { otherwise }
\end{array}\right.
$$

And the logit model is then specified as:

$$
P\left(F A I L_{i t}\right)=F\left(\beta_{0}+\beta_{1} S O_{i t}+\beta_{2} A Q_{i t}+\beta_{3} L I_{i t}+\beta_{4} P R_{i t}+\beta_{5} R E_{i t}+\beta_{6} F I_{i t}\right),
$$

where $\boldsymbol{F}(\cdot)$ is the logit function and the explanatory variables are solvency, asset quality, liquidity, profitability, relative size and fraction of insured deposits.

Table 3 presents the results of this estimation. We estimate four different specifications. In the first one we only include solvency and a constant as regressors. In the second we include all proxies of bank fundamentals while in the third and fourth specification we include specific controls such as relative size (RE) and the share of insured deposits (FI). The table shows that all proxies for bank fundamentals are significant at the 1 percent level in all specifications, and the respective coefficients have the expected sign. Note that we expect a positive sign for asset quality since we adopted the convention that lower values of asset quality are better. Interestingly, bank specific controls are not significant. The fact that poor performance embedded in the measures of bank fundamentals is indicative of future bank default, suggests that the measures we have constructed should indeed affect a bank's funding cost.

\section{Linear panel estimation}

To determine the relationship between bank fundamentals and funding cost we estimate the following baseline linear panel model:

$$
\boldsymbol{F C}_{i t}=\beta_{0}+\beta_{1} S O_{i t}+\beta_{2} A Q_{i t}+\beta_{3} L I_{i t}+\beta_{4} P R_{i t}+\sum_{t} \gamma_{t} Y_{t}+\varepsilon_{i t}
$$

The dependent variable $\boldsymbol{F} \boldsymbol{C}_{\boldsymbol{i t}}$ represents the bank's funding cost (proxied either by the average funding cost or the wholesale funding cost). The explanatory variables are the same as before: solvency, asset quality, liquidity and profitability. We added year dummies to capture all temporal effects.

$$
\boldsymbol{M 1}_{i t}=\beta_{0}+\beta_{1} S O_{i t}+\beta_{2} A Q_{i t}+\beta_{3} L I_{i t}+\beta_{4} P R_{i t}+\sum_{t} \gamma_{t} Y_{t}
$$

Starting from this baseline model, $\mathrm{M} 1_{\mathrm{it},}$ we estimate the following extended model:

$$
\boldsymbol{F} \boldsymbol{C}_{i t}=\boldsymbol{M 1 _ { i t }}+\beta_{5} R E_{i t}+\beta_{6} F I_{i t}+\beta_{7} F C_{i t-1}+\varepsilon_{i t}
$$

Finally, we estimate a model in which we replace the time dummies by the VIX $\left(V I X_{t}\right)$ and 10-year U.S. T-bill rate $\left(T B_{t}\right)$, in particular: 


$$
\boldsymbol{F C}_{i t}=\beta_{0}+\beta_{1} S O_{i t}+\beta_{2} A Q_{i t}+\beta_{3} L I_{i t}+\beta_{4} P R_{i t}+\beta_{8} V I X_{t}+\beta_{9} T B_{t}+\varepsilon_{i t}
$$

We estimate all the models using the Arellano-Bond Generalized Method of Moments (GMM) since our panel is large in the cross-sectional dimension relative to the temporal dimension. ${ }^{8}$ This technique automatically takes care of bank fixed effects, allows for weakly exogenous independent variables and lags of the dependent variable.

\section{Linear estimation by year}

We re-estimate the baseline linear model with simple ordinary least squares for every year in the sample to investigate how the sensitivity of funding cost to bank fundamentals changes over time. This yields a regression coefficient for each independent variable for every year in the sample.

\section{Non-linear estimation}

As noted earlier, a lender's response to shocks to the quality of bank fundamentals is not likely to be linear. The distribution of the wholesale funding cost conditional on the solvency measure SO seems to confirm this conjecture (Figure 1). As bank solvency decreases the wholesale funding cost distribution becomes more disperse, with an increasing number of observations with very large wholesale funding cost. At the same time the majority of observations are concentrated at relatively low values of wholesale funding cost. This suggests that under certain circumstances, low solvency can be associated with very large wholesale funding cost. In order to explore this further we estimate models with two different non-linear transformations of the solvency measure. In both cases we choose the non-linear transformation such that it allows for an increased sensitivity of wholesale funding cost to changes in solvency at low values of solvency.

The first non-linear model estimated is a simple piecewise linear regression with variable threshold $S O C$.

$$
\begin{gathered}
\boldsymbol{F C}_{i t}=\beta_{0}+\beta_{1} S O_{i t} I\left(S O_{i t}<S O C\right)+\beta_{2} S O_{i t} I\left(S O_{i t}>S O C\right)+M 2_{i t} \\
M 2_{i t}=\beta_{3} A Q_{i t}+\beta_{4} L I_{i t}+\beta_{5} P R_{i t}+\sum_{t} \gamma_{t} Y_{t}+\varepsilon_{i t}
\end{gathered}
$$

We estimate this model on the entire panel dataset for several different values of $S O C$, and choose the threshold that yields the best statistical fit, measured by the relative value of the pseudo R-square. This then identifies a critical value of solvency. Based on the intuitive argument above, we expect $\beta_{1}<\beta_{2}<0$, i.e. the sensitivity of lenders to solvency shocks below the critical value of solvency increases. We perform a T-test in order to assess whether the difference in the regression coefficients below and above SOC is significant. Thus

\footnotetext{
${ }^{8}$ See Arellano and Bover (1995) and Blundell and Bond (1998).
} 
piecewise linear regression allows us to identify whether there is evidence for an increased sensitivity to solvency shocks for low values of solvency.

As an alternative, we estimate a model with a two parameter non-linear transformation of the solvency measure of the following form:

$$
\boldsymbol{F C}_{\boldsymbol{i t}}=\beta_{0}+\beta_{1} \frac{1}{\left(S O_{i t}+\mu\right)^{z}}++\beta_{2} A Q_{i t}+\beta_{3} L I_{i t}+\beta_{4} P R_{i t}+\sum_{t} \gamma_{t} Y_{t}+\varepsilon_{i t}
$$

The offset parameter $\mu$ determines a critical value of solvency at which the funding cost diverges. Thus $\mu$ could be interpreted as the solvency threshold below which banks are shut out from the wholesale funding markets. The exponent $z$ determines the rate at which the sensitivity of wholesale investors to solvency shocks increases as solvency drops. The larger the $z$ the faster the investors' sensitivity will increase. We also estimate this model on the entire panel for several values of the offset and exponent parameters and select the parameters that yield the best statistical fit.

\section{B. Main Results}

The estimation of the linear and non-linear models described above yields the following results:

(i) The proxy for bank solvency is negatively related to both average and wholesale funding cost. This is apparent from columns 2 and 10 in Table 4 where we estimate the baseline specification of the linear model including only measures of bank fundamentals and year dummies as regressors. This result is robust to the inclusion of relative size and fraction of insured deposits as bank specific controls as well as the replacement of year dummies with the VIX and U.S. T-bill rate. This result suggests that when banks are subject to a solvency shock, investors will respond to the increase in default probability by raising the banks' funding cost. It should be noted however that these results are driven by cross-sectional variation rather than temporal variation. It may therefore not be straightforward to translate these results to the temporal evolution of the funding cost of an individual bank that suffers a solvency shock.

(ii) The sensitivity of wholesale funding cost to shocks in solvency is somewhat larger than the sensitivity of the average funding cost. This can be seen by comparing the estimated coefficient of the solvency measure for both average and wholesale funding cost presented in Table 4 columns 2 and 10, respectively. In particular, in these two regressions the estimated coefficients are equal to -0.0004 for wholesale funding cost and -0.0002 for average funding cost. This suggests that banks with a 1 percentage point lower level of solvency tend to pay 0.04 percentage points more on their wholesale liabilities. Similarly, they tend to pay 0.02 percentage points more on their total liabilities. Thus, in relative terms, the sensitivity of funding cost to solvency is stronger for wholesale funding cost than for average funding cost. This is consistent with the intuition that wholesale investors that provide unsecured loans to banks are more sensitive to counterparty risk than retail investors. 
(iii) Based on the results from the linear model, the magnitude of the solvency effect on funding cost is small. For example, a comparatively large solvency shock of 5 percentage points would only lead an average increase in interbank funding cost of approximately 0.2 percentage points. ${ }^{9}$ While this effect is small, it is important to keep in mind that such an increase in funding cost will tend to erode the bank's net interest margin and impair its ability to retain earnings and recover from the solvency shock. This distinguishes a solvency induced shock from a transitory shock, for example to the U.S. federal funds target rate, which is likely to affect both funding cost and asset returns and thereby have less of a direct effect on the bank's net interest margin. Thus, in principle, the results do not rule out the possibility of an adverse feedback loop between solvency and funding cost.

(iv) The sensitivity of wholesale investors to solvency is stronger during times of crisis. Yearly re-estimation of the relationship between solvency and funding cost shows that the sensitivity of interbank funding cost to solvency shocks varies significantly over the cycle (see Figures 2 and Figure 3). This contrasts to the results from the annual re-estimation of equations with average funding cost where the sensitivity is relatively stable over time. This finding suggests that during normal times wholesale investors are less likely to discipline banks based on their solvency levels, and is consistent with the clustered nature of bank failures and the correlation of failure events with broader economic downturns. In normal times wholesale investors tend to perceive the likelihood of bank failure as low and are less concerned about counterparty risk. However, when overall economic conditions deteriorate wholesale investors tend to discipline banks more heavily. Thus banks with relatively low levels of solvency that were, prior to a crisis, able to sustain moderate and stable funding costs, are likely to face a stronger response by lenders to further deteriorations in solvency. Note that this conclusion may be biased by the relatively short maturities on the interbank market and might therefore not translate to wholesale lending more generally.

(v) There is evidence that investors are more sensitive to solvency shocks for poorly capitalized banks. The results from the piecewise linear panel estimations reported in Table 5 show that the sensitivity of wholesale funding cost to solvency is larger in magnitude for banks with low levels of solvency than for strong banks. In fact, the sensitivity for poorly capitalized banks is more than twice as large as for well-capitalized banks. Furthermore a $t$ test indicates that this difference is statistically significant at a 5 percent significance level. While the distribution of wholesale funding cost conditional on the solvency measure

\footnotetext{
${ }^{9}$ The estimated elasticities of the response of funding cost to a solvency shock presented in Table 4 are indeed small in magnitude, albeit statistically significant in most cases. A possible explanation is the existence of a highly non-linear relationship, which cannot be captured by our simple core linear models. This underscores the importance of analyzing non-linearities between funding cost and bank fundamentals, as we do in subsequent models in this paper. However, these results are also a direct consequence of a simple characteristic in the observed data: whereas funding costs tend to "explode" for banks with low values of our solvency measure (Figure 1), which yields the expected negative relation between these two variables, it only happens for a relatively small number of banks. In other words, even among banks with weak fundamentals, funding costs tend to be very high for only a handful of them, whilst the vast majority of 'weak' banks would still exhibit relatively low funding costs.
} 
suggests an inverse relationship between wholesale funding cost and solvency (see Figure 1), we find that the introduction of the two-parameter non-linear transformation of solvency does not improve the model fit relative to the piecewise linear estimation (see Table 6 and Figure 4). This is likely due to the fact that a majority of the observations remains concentrated at low levels of wholesale funding cost even for low levels of solvency. Therefore, a strong inverse relationship between wholesale funding cost and solvency will fit the extreme outliers of wholesale funding cost better while missing the majority of observations with relatively low wholesale funding cost at low solvency. This of course reduces the goodness of fit of this inverse non-linear model. Ultimately, the data suggests that low solvency is a necessary but not sufficient condition for very high wholesale funding costs even when controlling for other aspects of the quality of bank fundamentals.

\section{Extension to a Global Bank Dataset}

In order to check whether our results using the FDIC dataset also hold for global financial institutions, we re-estimate our baseline model with data from SNL for a range of banks from advanced and emerging economies. We summarize the data in Table 7. In particular, we estimate the following model.

$$
\boldsymbol{F C}_{i t}=\beta_{0}+\beta_{1} S O_{i t}+\beta_{2} A Q_{i t}+\beta_{3} L I_{i t}+\beta_{4} P R_{i t}+\sum_{t} \gamma_{t} Y_{t}+\varepsilon_{i t}
$$

As before, the dependent variable $\boldsymbol{F} \boldsymbol{C}_{i t}$ represents the bank's average funding cost. The independent variables are as before: solvency, asset quality, liquidity and profitability. Furthermore, we have added year dummies, which automatically capture all temporal effects. We estimate the above model both using the fixed effects estimator and Arellano-Bond GMM estimator. The estimation results are summarized in Table 8.

As for the FDIC dataset, we find that funding cost is significantly negatively associated with changes in bank solvency.

\section{Summary AND CONCluSions}

The main results from the empirical analysis can be summarized as follows.

(1) Linear panel estimation shows that our solvency measure (comprised of the leverage ratio, Tier 1 capital ratio, and total regulatory capital ratio) is negatively and significantly related to both average and wholesale measures of funding cost. While the magnitude of the relationship is small, shocks to bank solvency can have a non negligible impact on the bank's profitability.

(2) On average, the coefficient linking funding cost and solvency is larger in magnitude for wholesale funding cost than for average funding cost. This is consistent with the notion that wholesale investors that provide unsecured loans to banks are more sensitive to counterparty risk than retail investors whose deposits are covered to a large extent by deposit insurance. 
(3) Re-estimation of the relationship between funding cost and solvency on a yearly basis shows that wholesale funding cost is more sensitive to solvency during periods of economic stress than in normal times. This finding is relevant from a stress testing perspective. The fact that the strength of the interaction between solvency and funding cost is state contingent introduces an additional factor of uncertainty into the stress testing process: when a severe enough crisis hits, historically estimated average sensitivities may be rendered invalid and underestimate the true sensitivity.

(4) There is evidence that the relationship between funding cost and solvency is non-linear, with higher sensitivity of funding cost at lower levels of solvency. While further work will be required to better quantify this non-linear relationship, our results suggest that banks with already low levels of solvency will be hit harder by funding cost increases making them even more susceptible to exogenous shocks.

These results have a number of implications. Increasing capital ratios may help banks reduce their cost of funding. Depending on the cost of raising additional capital it may be beneficial for banks to increase their capital in order to drive down their average funding cost. While this is a theoretical possibility, it is unclear whether the magnitude of the reduction in funding cost identified here would be sufficient to convince banks to increase their capital level.

Estimates of the sensitivity of bank funding cost to solvency shocks are critical for stresstesting, but the fact that the sensitivity of wholesale lenders to solvency shocks varies considerably over time and appears particularly elevated during times of crisis makes it hard to predict how funding cost will respond in future crises.

Furthermore, the non-linear estimations performed in this paper suggest that solvency should be viewed as an indicator of banks vulnerability to wholesale funding shocks. This adds to the view that the level of solvency is a determinant of funding cost. Banks with low capitalization are at risk of stark wholesale funding cost increases. However, whether or not such a funding cost increase materializes is likely to be conditional on other bank specific events that are notoriously hard to predict. This alternative interpretation suggests the following approach to funding cost stress testing. Rather than focusing on the mean of a heavily skewed distribution of funding cost conditional on a given level of solvency, an alternative approach would consider the probability of a particular funding cost spike conditional on a level of solvency.

Given an exogenous shock to bank solvency derived from a satellite model, a stress tester may use the funding cost elasticity, derived from the linear panel estimation, to compute changes in the overall interest expense of a stressed bank. However, it should be noted that the estimated increase in interest expense obtained through this procedure is likely to be conservative, and may underestimate the actual effect of a solvency shock in times of crisis. Based on this conservative estimate, the net interest margin of the stressed bank could be recomputed in order to project bank's earnings following the solvency shock. This would ultimately allow for the computation of a secondary solvency shock via the funding cost channel. 
Nevertheless, a better grasp of the nonlinearities at play in the response of funding cost to solvency shocks is crucial for improving the calibration of stress test models. As mentioned above, estimates of funding cost elasticity based on linear models are likely to underestimate the actual impact of solvency shocks on 'weak' banks. In particular, those models are not able to estimate a threshold value at which banks may be shut out from wholesale funding markets altogether. Furthermore, the models used in this paper probably place too strong emphasis on the mean of a skewed distribution of funding cost when outliers represent the events of actual importance for risk management and regulation.

Better data may help resolve some of the estimation issues. While the data available for this study allowed for a rough proxy of wholesale funding cost and the identification of linear sensitivities, an improved dataset could help make the conclusions of this study more robust and actionable. In particular data on wholesale funding cost (e.g., actual bond yields) and events of extreme funding liquidity tightening (including cases where liquidity completely dried out) would be useful. While data on the latter are rare, it is crucial to understand the nonlinear response of funding cost and the identification of a potentially state contingent solvency threshold for access to wholesale funding markets. 
Table 1. Pairwise Correlations of Funding Cost Variables, Constituent Variables of Measures of Bank Fundamentals and Measures of Bank Fundamentals

\begin{tabular}{|c|c|c|c|c|c|}
\hline & 1 & 2 & 3 & 4 & 5 \\
\hline 1 Average funding cost & 1 & & & & \\
\hline 2 Interbank funding cost & $0.3352 *$ & 1 & & & \\
\hline 3 Federal funds rate & $0.7976 *$ & $0.3551 *$ & 1 & & \\
\hline 4 U.S. T-Bill rate & $0.7290^{*}$ & $0.2892 *$ & $0.8413 *$ & 1 & \\
\hline $5 \mathrm{VIX}$ & -0.0018 & $-0.0707^{*}$ & $-0.2822 *$ & $-0.3100^{*}$ & 1 \\
\hline \multicolumn{6}{|l|}{${ }^{*} \mathrm{p}<0.05$} \\
\hline & 1 & 2 & 3 & & \\
\hline 1 Leverage ratio & 1 & & & & \\
\hline 2 Tier 1 capital ratio & $07776 *$ & 1 & & & \\
\hline 3 Total regulatory capital ratio & $0.7751^{*}$ & $0.9957^{*}$ & 1 & & \\
\hline \multicolumn{5}{|l|}{${ }^{*} \mathrm{p}<0.05$} & \\
\hline & 1 & 2 & $\frac{3}{3}$ & & \\
\hline 1 Liquid asscts to total asscts & 1 & & & & \\
\hline 2 Volatile liabilities to total liabilities & $-0.1200 *$ & 1 & & & \\
\hline 3 Deposits to total assets & $0.0567^{*}$ & $-0.5358^{*}$ & 1 & & \\
\hline
\end{tabular}

\begin{tabular}{|c|c|c|c|c|}
\hline & 1 & 2 & 3 & 4 \\
\hline 1 Net charge-offs to loans & 1 & & & \\
\hline 2 Credit loss provision to net charge-offs & $-0.2317^{*}$ & 1 & & \\
\hline 3 Earnings coverage of net charge offs & $0.3511 *$ & $0.3668 *$ & 1 & \\
\hline 4 Noncurrent loans to loans & $0.4626^{*}$ & $-0.1192 *$ & $-0.2666^{*}$ & 1 \\
\hline
\end{tabular}

\begin{tabular}{llrrr}
\hline & 1 & 2 & 3 \\
\hline 1 Return on equity & 1 & & \\
2 Return on assets & $09122^{*}$ & 1 & \\
3 Net interest margin & $0.3709^{*}$ & $0.3990^{*}$ & 1 \\
\hline${ }^{*} p<0.05$ & & &
\end{tabular}

\begin{tabular}{|c|c|c|c|c|}
\hline & 1 & 2 & 3 & 4 \\
\hline 1 Solvency & 1 & & & \\
\hline 2 Asset quality & -0.0074 & 1 & & \\
\hline 3 Profitability & 0.0063 & $-0.3977^{*}$ & 1 & \\
\hline 4 Liyuidity & $0.0826 *$ & $-0.0664 *$ & $0.0488^{*}$ & 1 \\
\hline
\end{tabular}


Table 2. Summary Statistics for FDIC Dataset

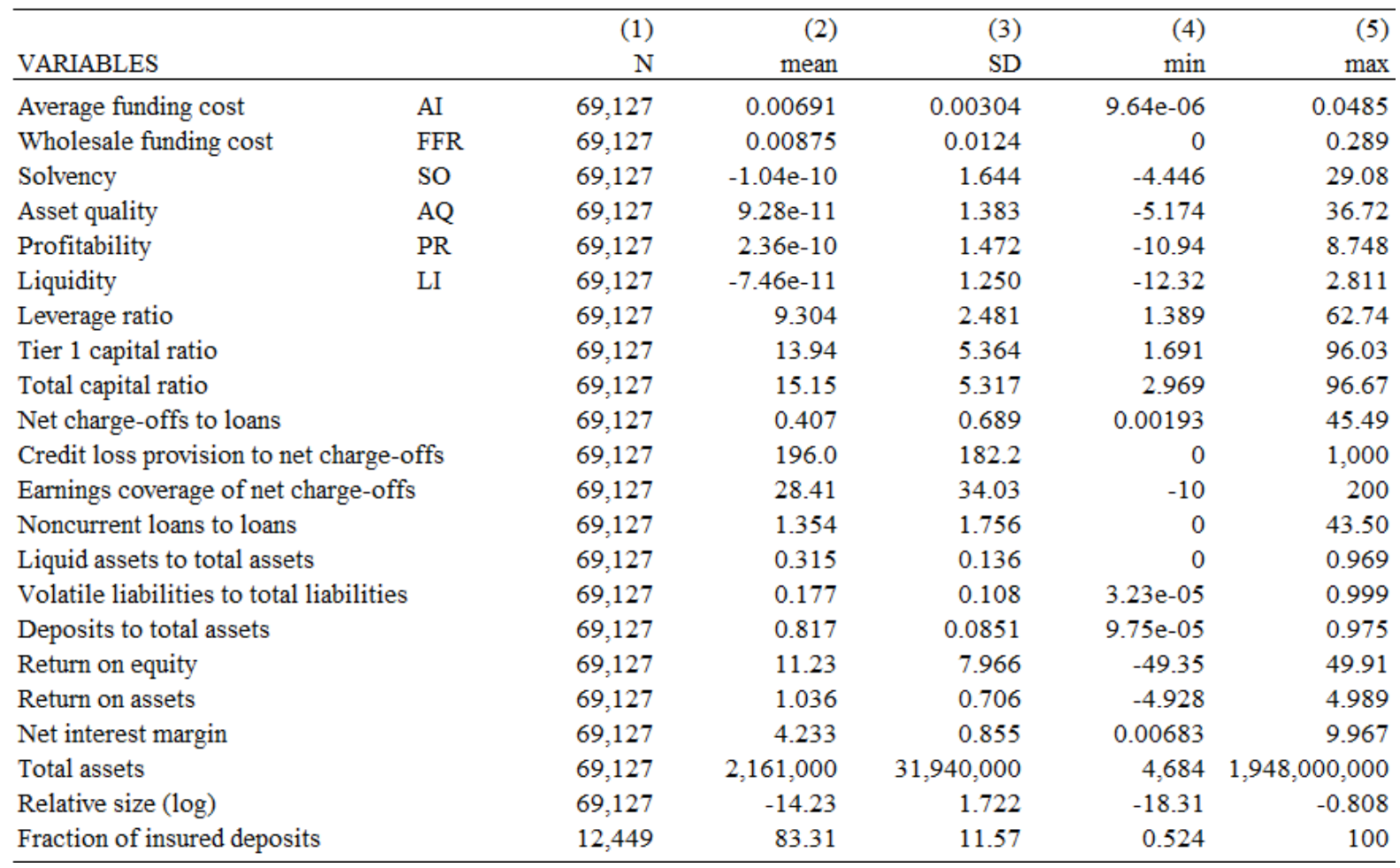

Note that values for solvency, asset quality, profitability and liquidity can take on negative values as they were constructed using Principal Component Analysis (PCA). 
Table 3. Estimates of Logit Model Linking Measures of Bank Fundamentals to Bank Default Probability in the FDIC Dataset

\begin{tabular}{|c|c|c|c|c|c|c|}
\hline \multirow{2}{*}{ VARIABLES } & & \multirow{2}{*}{$\begin{array}{l}\text { Expected } \\
\text { Sign }\end{array}$} & \multirow{2}{*}{$\begin{array}{r}\text { (1) } \\
\text { FAIL }\end{array}$} & \multirow{2}{*}{$\begin{array}{r}(2) \\
\text { FAIL }\end{array}$} & \multirow{2}{*}{$\begin{array}{r}\text { (3) } \\
\text { FAIL }\end{array}$} & \multirow{2}{*}{$\begin{array}{r}(4) \\
\text { FAIL }\end{array}$} \\
\hline & & & & & & \\
\hline Solvency & SO & Negative & $\begin{array}{r}-1.893 * * * \\
(0.102)\end{array}$ & $\begin{array}{r}-1.055^{* * * *} \\
(0.0963)\end{array}$ & $\begin{array}{r}-1.054 * * * \\
(0.0969)\end{array}$ & $\begin{array}{r}-1.369 * * * \\
(0.149)\end{array}$ \\
\hline Asset quality & $\mathrm{AQ}$ & Positive & & $\begin{array}{r}0.276 * * * \\
(0.0409)\end{array}$ & $\begin{array}{r}0.276 * * * \\
\quad(0.0410)\end{array}$ & $\begin{array}{r}0.428 * * * * \\
(0.0671)\end{array}$ \\
\hline Profitability & PR & Negative & & $\begin{array}{r}-0.434 * * * * \\
(0.0393)\end{array}$ & $\begin{array}{r}-0.434 * * * * \\
(0.0394)\end{array}$ & $\begin{array}{r}-0.167 * * \\
(0.0661)\end{array}$ \\
\hline Liquidity & LI & Negative & & $\begin{array}{r}-0.313 * * * \\
(0.0398)\end{array}$ & $\begin{array}{r}-0.311^{* * * *} * \\
(0.0420)\end{array}$ & $\begin{array}{r}-0.513 * * * * \\
(0.105)\end{array}$ \\
\hline Relative size & $\mathrm{RE}$ & Negative & & & $\begin{array}{r}0.00706 \\
(0.0465)\end{array}$ & $\begin{array}{l}-0.124 \\
(0.0937)\end{array}$ \\
\hline Fraction of insured deposits & FI & Negative & & & & $\begin{array}{r}-0.0131 \\
(0.0121)\end{array}$ \\
\hline & Constant & & $\begin{array}{r}-7.928 * * * * \\
(0.175)\end{array}$ & $\begin{array}{r}-8.071^{* * * *} \\
(0.187)\end{array}$ & $\begin{array}{r}-7.972 * * * * \\
(0.679)\end{array}$ & $\begin{array}{r}-8.666 * * * \\
(1.347)\end{array}$ \\
\hline Observations & & & 69,127 & 69,127 & 69,127 & 12,449 \\
\hline
\end{tabular}

Standard errors in parentheses

$* * * \mathrm{p}<0.01, * * \mathrm{p}<0.05, * \mathrm{p}<0.1$ 
Table 4. Estimation Results for Linear Panel Estimation with Arellano-Bond

Al: Average funding cost. FFR: Wholesale funding cost.

\begin{tabular}{|c|c|c|c|c|c|c|c|c|c|c|c|c|c|c|c|c|c|}
\hline Solvency & so & $\begin{array}{r}-00002 * \cdots * \\
(0.0000)\end{array}$ & $\begin{array}{r}-00002 * * * \\
(0.0000)\end{array}$ & $\begin{array}{r}-00003 * \cdots \\
(0.0000)\end{array}$ & $\begin{array}{r}-00002 * * * \\
(0.0000)\end{array}$ & $\begin{array}{r}-00000^{* * * *} \\
(0.0000)\end{array}$ & $\begin{array}{l}-00000 \\
(0.0000)\end{array}$ & $\begin{array}{r}-00003 * \cdots \\
(0.0001)\end{array}$ & $\begin{array}{r}-00003 * * * \\
(0.0000)\end{array}$ & $\begin{array}{r}-00003 * * \\
(0.0001)\end{array}$ & $\begin{array}{r}-00004 * \cdots * \\
(0.0001)\end{array}$ & $\begin{array}{r}-00004 * * * \\
(0.0001)\end{array}$ & $\begin{array}{r}-00002^{*} \\
(0.0001)\end{array}$ & $\begin{array}{r}-0.0003 * * \\
(0.0001)\end{array}$ & $\begin{array}{l}-00000 \\
(0.0001)\end{array}$ & $\begin{array}{r}-00005 * * * \\
(0.0002)\end{array}$ & $\begin{array}{r}-00006^{* * *} \\
(0.0002)\end{array}$ \\
\hline Asset quality & $\mathrm{AQ}$ & & $\begin{array}{r}-0.0001^{* * *} \\
(0.0000)\end{array}$ & $\begin{array}{c}-0.0001^{* * *} \\
(0.0000)\end{array}$ & $\begin{array}{r}-0.0001^{* * * *} \\
(0.0000)\end{array}$ & $\begin{array}{r}-0.0001 * * * \\
(0.0000)\end{array}$ & $\begin{array}{r}-0.0001 * * * \\
(0.0000)\end{array}$ & $\begin{array}{r}-0.0006^{* * *} \\
(0.0000)\end{array}$ & $\begin{array}{r}-0.0006^{* * * *} \\
(0.0000)\end{array}$ & & $\begin{array}{r}0.0002 * * \\
(0.0001)\end{array}$ & $\begin{array}{r}0.0002 * * * \\
(0.0001)\end{array}$ & $\begin{array}{l}0.0001^{*} \\
(0.0001)\end{array}$ & $\begin{array}{l}-0.0000 \\
(0.0001)\end{array}$ & $\begin{array}{r}0.0001 \\
(0.0001)\end{array}$ & $\begin{array}{r}-0.0005 * * * \\
(0.0001)\end{array}$ & $\begin{array}{r}-0.0004 * * * \\
(0.0002)\end{array}$ \\
\hline Profitability & PR & & $\begin{array}{r}-00003 \cdots \cdots \\
(0.0000)\end{array}$ & $\begin{array}{r}-00003 * \cdots * \\
(0.0000)\end{array}$ & $\begin{array}{r}-00003 * \cdots \\
(0.0000)\end{array}$ & $\begin{array}{r}-00001 * . * \\
(0.0000)\end{array}$ & $\begin{array}{r}-00000^{* *} \\
(0.0000)\end{array}$ & $\begin{array}{r}-00004 * * * \\
(0.0001)\end{array}$ & $\begin{array}{r}-00003 * \cdots \\
(0.0000)\end{array}$ & & $\begin{array}{r}00001 \\
(0.0001)\end{array}$ & $\begin{array}{r}00001 \\
(0.0001)\end{array}$ & $\begin{array}{r}00000 \\
(0.0001)\end{array}$ & $\begin{array}{l}-0.0001 \\
(0.0001)\end{array}$ & $\begin{array}{r}00000 \\
(0.0001)\end{array}$ & $\begin{array}{r}00001 \\
(0.0002)\end{array}$ & $\begin{array}{r}00001 \\
(0.0002)\end{array}$ \\
\hline Liquidity & LI & & $\begin{array}{r}-0.0003 * * * \\
(0.0000)\end{array}$ & $\begin{array}{r}-0.0004 * * * \\
(0.0000)\end{array}$ & $\begin{array}{l}-0.0001 \\
(0.0001)\end{array}$ & $\begin{array}{r}-0.0001 * * * \\
(0.0000)\end{array}$ & $\begin{array}{r}0.0000 \\
(0.0000)\end{array}$ & $\begin{array}{r}-0.0009 * * * \\
(0.0000)\end{array}$ & $\begin{array}{r}-0.0006 * * * \\
(0.0000)\end{array}$ & & $\begin{array}{r}-0.0003 * * \\
(0.0001)\end{array}$ & $\begin{array}{l}-0.0002 \\
(0.0002)\end{array}$ & $\begin{array}{r}0.0002 \\
(0.0002)\end{array}$ & $\begin{array}{l}-0.0001 \\
(0.0001)\end{array}$ & $\begin{array}{r}0.0002 \\
(0.0002)\end{array}$ & $\begin{array}{r}-0.0007 * * * \\
(0.0001)\end{array}$ & $\begin{array}{r}-0.0008 * * * \\
(0.0001)\end{array}$ \\
\hline Relative size & & & & $\begin{array}{r}-0.0002 * * * \\
(0.0000)\end{array}$ & $\begin{array}{l}-0.0000 \\
(0.0000)\end{array}$ & & $\begin{array}{r}-0.0000^{* *} \\
(0.0000)\end{array}$ & & & & & $\begin{array}{r}0.0002^{* *} \\
(0.0001)\end{array}$ & $\begin{array}{r}0.0003 * * \\
(0.0001)\end{array}$ & & $\begin{array}{r}0.0001 \\
(0.0001)\end{array}$ & & \\
\hline vIX & & & & & & & & & $\begin{array}{r}0.0001^{* * *} \\
(0.0000)\end{array}$ & & & & & & & & $\begin{array}{r}-0.0000 * * * \\
(0.0000)\end{array}$ \\
\hline T-Bill 10 year & & & & & & & & $\begin{array}{r}0.1447^{* * *} \\
(0.0012)\end{array}$ & $\begin{array}{r}0.1515 * * * \\
(00012)\end{array}$ & & & & & & & $\begin{array}{r}0.2181^{* * *} \\
(0.050)\end{array}$ & $\begin{array}{r}0.2164^{* * *} \\
(0.0050)\end{array}$ \\
\hline Fraction of insured deposits & & & & & $\begin{array}{r}0.0000 * * * \\
(0.0000)\end{array}$ & & $\begin{array}{r}0.0000 \\
(0.0000)\end{array}$ & & & & & & $\begin{array}{r}0.0000 \\
(0.0000)\end{array}$ & & $\begin{array}{r}0.0000 \\
(0.0000)\end{array}$ & & \\
\hline Lagged dependent variable & & & & & & $\begin{array}{r}0.6299^{* * *} \\
(00279)\end{array}$ & $\begin{array}{r}0.7469 * * * \\
(0.0728)\end{array}$ & & & & & & & $\begin{array}{r}0.0196 \\
(0.0691)\end{array}$ & $\begin{array}{r}0.2897 * * * \\
(00933)\end{array}$ & & \\
\hline Constant & & $\begin{array}{r}0.0015 * * * \\
(0.0000)\end{array}$ & $\begin{array}{r}0.0016 * * * \\
(0.0000)\end{array}$ & $\begin{array}{r}0.0010 * * * \\
(0.0003)\end{array}$ & $\begin{array}{r}0.0003 \\
(0.0004)\end{array}$ & $\begin{array}{r}0.0003 * * * \\
(0.0001)\end{array}$ & $\begin{array}{r}0.0005^{* * *} \\
(0.0001)\end{array}$ & $\begin{array}{r}0.0001^{* *} \\
(0.0001)\end{array}$ & $\begin{array}{r}0.0017 * * * \\
(0.0001)\end{array}$ & $\begin{array}{r}0.0016^{* * *} \\
(0.0001)\end{array}$ & $\begin{array}{r}0.0018^{* * *} \\
(0.0001)\end{array}$ & $\begin{array}{r}0.0046^{* * *} \\
(0.0011)\end{array}$ & $\begin{array}{r}0.0035^{* * *} \\
(0.0013)\end{array}$ & $\begin{array}{r}0.0015^{* * *} \\
(0.0002)\end{array}$ & $\begin{array}{r}0.0010 \\
(0.0009)\end{array}$ & $\begin{array}{r}0.0024^{* * *} \\
(0.0002)\end{array}$ & $\begin{array}{r}0.0018 * * * \\
(0.0003)\end{array}$ \\
\hline Observations & & 69,127 & 69,127 & 69,127 & 12,449 & 47,071 & 10,086 & 69,127 & 69,127 & 69,127 & 69,127 & 69,127 & 12,449 & 47,071 & 10,086 & 69,127 & 69,127 \\
\hline Number of banks & & 10,707 & 10,707 & 10,707 & 4,131 & 8,023 & 3,187 & 10,707 & 10,707 & 10,707 & 10,707 & 10,707 & 4,131 & 8,023 & 3,187 & 10,707 & 10,707 \\
\hline Time dummy & & YES & YES & YES & YES & YES & YES & YES & NO & YES & YES & YES & YES & YES & YES & YES & No \\
\hline Method & & GMM & GMM & GMM & GMM & GMM & GMM & GMM & GMM & GMM & GMM & GMM & GMM & GMM & GMM & GMM & GMM \\
\hline Pseudo R2 & & 0.7486 & 0.7784 & 0.7773 & 0.5923 & 0.9104 & 0.9169 & 0.4975 & 0.5544 & 0.1302 & 0.1299 & 0.1304 & 0.0194 & 0.1758 & 0.1051 & 0.0854 & 0.0840 \\
\hline Lags & & $2-7$ & $2-7$ & $2-7$ & $2-7$ & $2-7$ & $2-7$ & $2-7$ & $2-7$ & $2-7$ & $2-7$ & $2-7$ & $2-7$ & $2-7$ & $2-7$ & $2-7$ & $2-7$ \\
\hline Number of instruments & & 132 & 472 & 583 & 155 & 575 & 184 & 453 & 454 & 132 & 472 & 583 & 155 & 575 & 184 & 453 & 454 \\
\hline Hansen Test & & 0.0000 & 0.0000 & 0.0000 & 0.0000 & 0.0000 & 0.0000 & 0.0000 & 0.0000 & 0.7100 & 0.6290 & 0.0884 & 0.2530 & 0.1020 & 0.0033 & 0.0000 & 0.0000 \\
\hline $\operatorname{AR}(1)$ & & $6.89 \mathrm{e}-08$ & $9.49 \mathrm{e}-09$ & $1.25 \mathrm{e}-08$ & 0.0983 & 0.0000 & 0.0000 & 0.0000 & 0.0000 & 0.0000 & 0.0000 & 0.0000 & 0.0412 & $1.82 \mathrm{e}-09$ & 0.0126 & 0.0000 & 0.0000 \\
\hline
\end{tabular}


Table 5. Estimation Results for Piecewise Panel Estimation with Arellano-Bond

FFR: wholesale funding cost. SOC: threshold for piecewise linear estimation.

\begin{tabular}{|c|c|c|c|c|c|c|c|c|c|c|c|c|c|}
\hline VARIABLES & & $\begin{array}{c}\text { (1) } \\
\text { FFR } \\
\text { Baseline }\end{array}$ & $\begin{array}{l}\text { (2) } \\
\text { FFR }\end{array}$ & $\begin{array}{l}\text { (3) } \\
\text { FFR }\end{array}$ & $\begin{array}{l}\text { (4) } \\
\text { FFR }\end{array}$ & $\begin{array}{l}\text { (5) } \\
\text { FFR }\end{array}$ & $\begin{array}{l}\text { (6) } \\
\text { FFR }\end{array}$ & $\begin{array}{l}\text { (7) } \\
\text { FFR }\end{array}$ & $\begin{array}{c}(8) \\
\text { FFR }\end{array}$ & $\begin{array}{l}\text { (9) } \\
\text { FFR }\end{array}$ & $\begin{array}{l}\text { (10) } \\
\text { FFR }\end{array}$ & $\begin{array}{l}\text { (11) } \\
\text { FFR }\end{array}$ & $\begin{array}{l}\text { (12) } \\
\text { FFR }\end{array}$ \\
\hline Solvency & SO & $\begin{array}{r}-0.0005 * * * \\
(0.0001)\end{array}$ & & & & & & & & & & & \\
\hline Asset quality & $\mathrm{AQ}$ & $\begin{array}{r}0.0000 \\
(0.0000)\end{array}$ & $\begin{array}{r}0.0000 \\
(0.0001)\end{array}$ & $\begin{array}{r}0.0001 \\
(0.0001)\end{array}$ & $\begin{array}{r}0.0000 \\
(0.0000)\end{array}$ & $\begin{array}{r}0.0000 \\
(0.0000)\end{array}$ & $\begin{array}{r}0.0000 \\
(0.0000)\end{array}$ & $\begin{array}{r}0.0000 \\
(0.0000)\end{array}$ & $\begin{array}{r}0.0000 \\
(0.0000)\end{array}$ & $\begin{array}{r}0.0000 \\
(0.0000)\end{array}$ & $\begin{array}{r}0.0000 \\
(0.0001)\end{array}$ & $\begin{array}{r}0.0000 \\
(0.0001)\end{array}$ & $\begin{array}{r}0.0000 \\
(0.0001)\end{array}$ \\
\hline Profitability & PR & $\begin{array}{l}-0.0000 \\
(0.0001)\end{array}$ & $\begin{array}{r}0.0000 \\
(0.0001)\end{array}$ & $\begin{array}{r}0.0000 \\
(0.0001)\end{array}$ & $\begin{array}{l}-0.0000 \\
(0.0001)\end{array}$ & $\begin{array}{r}0.0000 \\
(0.0001)\end{array}$ & $\begin{array}{r}0.0000 \\
(0.0001)\end{array}$ & $\begin{array}{l}-0.0000 \\
(0.0001)\end{array}$ & $\begin{array}{l}-0.0000 \\
(0.0001)\end{array}$ & $\begin{array}{l}-0.0000 \\
(0.0001)\end{array}$ & $\begin{array}{l}-0.0000 \\
(0.0001)\end{array}$ & $\begin{array}{r}0.0000 \\
(0.0001)\end{array}$ & $\begin{array}{l}-0.0001 \\
(0.0001)\end{array}$ \\
\hline Liquidity & LI & $\begin{array}{r}-0.0007 * * * \\
(0.0001)\end{array}$ & $\begin{array}{r}-0.0008 * * * \\
(0.0002)\end{array}$ & $\begin{array}{r}-0.0007 * * * \\
(0.0002)\end{array}$ & $\begin{array}{r}-0.0007 * * * \\
(0.0001)\end{array}$ & $\begin{array}{r}-0.0007 * * * \\
(0.0001)\end{array}$ & $\begin{array}{r}-0.0007 * * * \\
(0.0001)\end{array}$ & $\begin{array}{r}-0.0007 * * * \\
(0.0001)\end{array}$ & $\begin{array}{r}-0.0007 * * * \\
(0.0001)\end{array}$ & $\begin{array}{r}-0.0007 * * * \\
(0.0001)\end{array}$ & $\begin{array}{r}-0.0007 * * * \\
(0.0001)\end{array}$ & $\begin{array}{r}-0.0008 * * * \\
(0.0002)\end{array}$ & $\begin{array}{r}-0.0010 * * * \\
(0.0002)\end{array}$ \\
\hline Solvency below SOC & $\mathrm{SO}<\mathrm{SOC}$ & & $\begin{array}{l}-0.0009 \\
(0.0006)\end{array}$ & $\begin{array}{r}-0.0004^{*} \\
(0.0002)\end{array}$ & $\begin{array}{r}-0.0007 * * * \\
(0.0001)\end{array}$ & $\begin{array}{r}-0.0007 * * * \\
(0.0002)\end{array}$ & $\begin{array}{r}-0.0006 * * * \\
(0.0001)\end{array}$ & $\begin{array}{r}-0.0005 * * * \\
(0.0001)\end{array}$ & $\begin{array}{r}-0.0006^{* * * *} \\
(0.0001)\end{array}$ & $\begin{array}{r}-0.0006 * * * \\
(0.0001)\end{array}$ & $\begin{array}{r}-0.0006 * * * \\
(0.0001)\end{array}$ & $\begin{array}{r}-0.0006^{* * * *} \\
(0.0001)\end{array}$ & $\begin{array}{r}-0.0005 * * * \\
(0.0001)\end{array}$ \\
\hline Solvency above SOC & $\mathrm{SO}>\mathrm{SOC}$ & & $\begin{array}{r}-0.0005^{* * *} \\
(0.0001)\end{array}$ & $\begin{array}{r}-0.0004 * * * \\
(0.0001)\end{array}$ & $\begin{array}{r}-0.0003 * * * \\
(0.0001)\end{array}$ & $\begin{array}{r}-0.0002 * * \\
(0.0001)\end{array}$ & $\begin{array}{r}-0.0003 * * * \\
(0.0001)\end{array}$ & $\begin{array}{r}-0.0004 * * * \\
(0.0001)\end{array}$ & $\begin{array}{r}-0.0006 * * * \\
(0.0002)\end{array}$ & $\begin{array}{r}-0.0004 * * * \\
(0.0001)\end{array}$ & $\begin{array}{r}-0.0002 * \\
(0.0001)\end{array}$ & $\begin{array}{l}-0.0001 \\
(0.0001)\end{array}$ & $\begin{array}{l}-0.0001 \\
(0.0002)\end{array}$ \\
\hline Constant & & $\begin{array}{r}0.0021 * * * \\
(0.0001)\end{array}$ & $\begin{array}{r}0.0021 * * * \\
(0.0002)\end{array}$ & $\begin{array}{r}0.0021 * * * * \\
(0.0001)\end{array}$ & $\begin{array}{r}0.0019 * * * \\
(0.0001)\end{array}$ & $\begin{array}{r}0.0081 * * * \\
(0.0003)\end{array}$ & $\begin{array}{r}0.0083 * * * \\
(0.0002)\end{array}$ & $\begin{array}{r}0.0020 * * * \\
(0.0001)\end{array}$ & $\begin{array}{r}0.0020 * * * \\
(0.0001)\end{array}$ & $\begin{array}{r}0.0020 * * * \\
(0.0001)\end{array}$ & $\begin{array}{r}0.0020 * * * \\
(0.0001)\end{array}$ & $\begin{array}{r}0.0084 * * * \\
(0.0002)\end{array}$ & $\begin{array}{r}0.0086^{* * *} \\
(0.0002)\end{array}$ \\
\hline Observations & & 69,127 & 69,127 & 69,127 & 69,127 & 69,127 & 69,127 & 69,127 & 69,127 & 69,127 & 69,127 & 69,127 & 69,127 \\
\hline Number of cert & & 10,707 & 10,707 & 10,707 & 10,707 & 10,707 & 10,707 & 10,707 & 10,707 & 10,707 & 10,707 & 10,707 & 10,707 \\
\hline Time dummy & & YES & YES & YES & YES & YES & YES & YES & YES & YES & YES & YES & YES \\
\hline Method & & GMM & GMM & GMM & GMM & GMM & GMM & GMM & GMM & GMM & GMM & GMM & GMM \\
\hline Pseudo R2 & & 0.1283 & 0.1276 & 0.1284 & 0.1291 & 0.1291 & 0.1286 & 0.1283 & 0.1278 & 0.1284 & 0.1286 & 0.1273 & 0.1259 \\
\hline $\mathrm{SOC}$ & & $\mathrm{NA}$ & -3 & -2 & -1 & 0 & 1 & 2 & 3 & 4 & 5 & 6 & 7 \\
\hline Number of instruments & & 317 & 328 & 390 & 390 & 390 & 390 & 390 & 390 & 390 & 390 & 390 & 390 \\
\hline Hansen Test & & 0.124 & 0.120 & 0.254 & 0.0222 & 0.000403 & 0.00306 & 0.223 & 0.179 & 0.277 & 0.222 & 0.168 & 0.259 \\
\hline $\mathrm{AR}(1)$ & & 0 & 0 & 0 & 0 & 0 & 0 & 0 & 0 & 0 & 0 & 0 & 0 \\
\hline$T$ test $p$ value & & & 0.4274 & 0.8902 & 0.0132 & 0.0555 & 0.1334 & 0.4789 & 0.8952 & 0.0690 & 0.0193 & 0.0017 & 0.0220 \\
\hline T statistic & & & -0.7937 & 0.1380 & -2.4799 & -1.9154 & -1.5009 & -0.7081 & 0.1318 & -1.8186 & -2.3406 & -3.1446 & -2.2909 \\
\hline
\end{tabular}

*** $p<0.01, * * p<0.05, * p<0.1$ 
Table 6. Estimation Results for Panel Estimation with Arellano-Bond of Model with Two Parameter Non-linear Transform of Solvency

FFR: wholesale funding cost. SOT: non-linear transform of solvency. Mu: offset parameter. $z$ : exponent. We choose $z=6$ since this yields the highest pseudo R squared and show the results for different values of the offset parameter mu.

\begin{tabular}{|c|c|c|c|c|c|c|c|c|c|c|c|c|}
\hline VARIABLES & & $\begin{array}{l}(1) \\
\text { FFR }\end{array}$ & $\begin{array}{l}(2) \\
\text { FFR }\end{array}$ & $\begin{array}{l}\text { (3) } \\
\text { FFR }\end{array}$ & $\begin{array}{l}(4) \\
\text { FFR }\end{array}$ & $\begin{array}{l}(5) \\
\text { FFR }\end{array}$ & $\begin{array}{l}(6) \\
\text { FFR }\end{array}$ & $\begin{array}{l}(7) \\
\text { FFR }\end{array}$ & $\begin{array}{l}(8) \\
\text { FFR }\end{array}$ & $\begin{array}{l}(9) \\
\text { FFR }\end{array}$ & $\begin{array}{l}\text { (10) } \\
\text { FFR }\end{array}$ & $\begin{array}{l}\text { (11) } \\
\text { FFR }\end{array}$ \\
\hline Solvency transform & SOT & $\begin{array}{r}0.4487 \\
(0.4586)\end{array}$ & $\begin{array}{r}1.9318 \\
(1.6596)\end{array}$ & $\begin{array}{r}6.1895 \\
(4.2594)\end{array}$ & $\begin{array}{r}16.1166^{*} \\
(8.8150)\end{array}$ & $\begin{array}{r}36.2252^{* *} \\
(16.2987)\end{array}$ & $\begin{array}{r}73.2948 * * * \\
(28.4082)\end{array}$ & $\begin{array}{r}137.0340^{* * * *} \\
(47.5070)\end{array}$ & $\begin{array}{r}240.6911^{* * *} \\
(76.5965)\end{array}$ & $\begin{array}{r}401.7111^{* * *} \\
(119.4161)\end{array}$ & $\begin{array}{r}642.4909 * * * \\
(180.6025)\end{array}$ & $\begin{array}{r}991.2400 * * * \\
\quad(265.8680)\end{array}$ \\
\hline Asset quality & $\mathrm{AQ}$ & $\begin{array}{r}0.0000 \\
(0.0000)\end{array}$ & $\begin{array}{r}0.0000 \\
(0.0000)\end{array}$ & $\begin{array}{r}0.0000 \\
(0.0000)\end{array}$ & $\begin{array}{r}0.0000 \\
(0.0000)\end{array}$ & $\begin{array}{r}0.0000 \\
(0.0000)\end{array}$ & $\begin{array}{r}0.0000 \\
(0.0000)\end{array}$ & $\begin{array}{r}0.0000 \\
(0.0000)\end{array}$ & $\begin{array}{r}0.0000 \\
(0.0000)\end{array}$ & $\begin{array}{r}0.0000 \\
(0.0000)\end{array}$ & $\begin{array}{r}0.0000 \\
(0.0000)\end{array}$ & $\begin{array}{r}0.0000 \\
(0.0000)\end{array}$ \\
\hline Profitability & PR & $\begin{array}{l}-0.0001 \\
(0.0001)\end{array}$ & $\begin{array}{l}-0.0001 \\
(0.0001)\end{array}$ & $\begin{array}{l}-0.0001 \\
(0.0001)\end{array}$ & $\begin{array}{l}-0.0001 \\
(0.0001)\end{array}$ & $\begin{array}{l}-0.0000 \\
(0.0001)\end{array}$ & $\begin{array}{l}-0.0000 \\
(0.0001)\end{array}$ & $\begin{array}{l}-0.0000 \\
(0.0001)\end{array}$ & $\begin{array}{l}-0.0000 \\
(0.0001)\end{array}$ & $\begin{array}{r}0.0000 \\
(0.0001)\end{array}$ & $\begin{array}{r}0.0000 \\
(0.0001)\end{array}$ & $\begin{array}{r}0.0000 \\
(0.0001)\end{array}$ \\
\hline Liquidity & LI & $\begin{array}{r}-0.0007 * * * \\
(0.0002)\end{array}$ & $\begin{array}{r}-0.0007 * * * \\
(0.0002)\end{array}$ & $\begin{array}{r}-0.0007 * * * \\
(0.0002)\end{array}$ & $\begin{array}{r}-0.0007 * * * \\
(0.0002)\end{array}$ & $\begin{array}{r}-0.0007^{* * *} \\
(0.0002)\end{array}$ & $\begin{array}{r}-0.0007 * * * \\
(0.0002)\end{array}$ & $\begin{array}{r}-0.0007 * * * \\
(0.0002)\end{array}$ & $\begin{array}{r}-0.0007 * * * \\
(0.0002)\end{array}$ & $\begin{array}{r}-0.0007^{* * *} \\
(0.0002)\end{array}$ & $\begin{array}{r}-0.0007 * * * \\
(0.0002)\end{array}$ & $\begin{array}{r}-0.0008^{* * * *} \\
(0.0002)\end{array}$ \\
\hline & Constant & $\begin{array}{r}0.0084^{* * *} \\
(0.0002)\end{array}$ & $\begin{array}{r}0.0084 * * * \\
(0.0002)\end{array}$ & $\begin{array}{r}0.0083 * * * \\
(0.0002)\end{array}$ & $\begin{array}{r}0.0083 * * * \\
(0.0002)\end{array}$ & $\begin{array}{r}0.0082^{* * *} \\
(0.0003)\end{array}$ & $\begin{array}{r}0.0081^{* * * *} \\
(0.0003)\end{array}$ & $\begin{array}{r}0.0080 * * * \\
(0.0003)\end{array}$ & $\begin{array}{r}0.0079 * * * \\
(0.0003)\end{array}$ & $\begin{array}{r}0.0079 * * * \\
(0.0003)\end{array}$ & $\begin{array}{r}0.0078^{* * *} \\
(0.0003)\end{array}$ & $\begin{array}{r}0.0077 * * * \\
(0.0003)\end{array}$ \\
\hline Observations & & 69,127 & 69,127 & 69,127 & 69,127 & 69,127 & 69,127 & 69,127 & 69,127 & 69,127 & 69,127 & 69,127 \\
\hline Number of banks & & 10,707 & 10,707 & 10,707 & 10,707 & 10,707 & 10,707 & 10,707 & 10,707 & 10,707 & 10,707 & 10,707 \\
\hline Time dummy & & YES & YES & YES & YES & YES & YES & YES & YES & YES & YES & YES \\
\hline Method & & GMM & GMM & GMM & GMM & GMM & GMM & GMM & GMM & GMM & GMM & GMM \\
\hline Pseudo R2 & & 0.1274 & 0.1276 & 0.1277 & 0.1279 & 0.1280 & 0.1281 & 0.1282 & 0.1282 & 0.1283 & 0.1283 & 0.1283 \\
\hline Lags & & $1-3$ & $1-3$ & $1-3$ & $1-3$ & $1-3$ & $1-3$ & $1-3$ & $1-3$ & $1-3$ & $1-3$ & $1-3$ \\
\hline $\mathrm{mu}$ & & 6 & 6.5 & 7 & 7.5 & 8 & 8.5 & 9 & 9.5 & 10 & 10.5 & 11 \\
\hline Number of instruments & & 317 & 317 & 317 & 317 & 317 & 317 & 317 & 317 & 317 & 317 & 317 \\
\hline Hansen Test & & 0.0007 & 0.0004 & 0.0003 & 0.0002 & 0.0002 & 0.0002 & 0.0002 & 0.0001 & 0.0001 & 0.0001 & 0.0001 \\
\hline $\operatorname{AR}(1)$ & & 0 & 0 & 0 & 0 & 0 & 0 & 0 & 0 & 0 & 0 & 0 \\
\hline z & & 6 & 6 & 6 & 6 & 6 & 6 & 6 & 6 & 6 & 6 & 6 \\
\hline
\end{tabular}


Table 7. Summary Statistics for SNL Dataset

\begin{tabular}{|c|c|c|c|c|c|c|}
\hline Variable & Name & $\mathrm{N}$ & Mean & $\mathrm{SD}$ & Min & $\operatorname{Max}$ \\
\hline $\mathrm{SO}$ & Solvency & 17,625 & 0.000 & 1.638 & -3.452 & 30.253 \\
\hline $\mathrm{t} 1 \mathrm{r}$ & Tier 1 Ratio & 17,999 & 14.506 & 7.227 & 0.540 & 98.600 \\
\hline rbcr & Risk-based Capital Ratio & 17,999 & 16.048 & 7.112 & 1.070 & 99.900 \\
\hline toteq totassets & Total Equity/Total Assets & 17,997 & 10.044 & 4.775 & 0.200 & 89.770 \\
\hline $\mathrm{t} 1 \mathrm{a}^{-}$ & Tier 1 Capital/Total Assets & 17,627 & 14.781 & 480.939 & 0.004 & 61703.230 \\
\hline AT & Asset Trouble & 13,420 & 0.000 & 1.681 & -5.032 & 24.731 \\
\hline aq3 & Problem Loans/ Gross Total Loans & 17,999 & 3.190 & 6.668 & 0.000 & 99.910 \\
\hline aq19 & Loan Loss Reserves/ Problem Loans & 15,681 & 162.904 & 181.198 & 0.000 & 998.540 \\
\hline aq31 & Reserves/ NPLs & 13,440 & 176.971 & 188.804 & 0.000 & 998.540 \\
\hline nplr & Nonperforming Loans/Total Net Loans & 15,709 & 2.361 & 3.783 & 0.000 & 94.483 \\
\hline LI & Liquidity & 17,986 & 0.000 & 1.467 & -19.575 & 2.797 \\
\hline liq12 & Liquid Assets/ Total Assets & 17,999 & 25.852 & 13.310 & 0.330 & 95.680 \\
\hline liq13 & Liquid Assets/ Total Liabilities & 17,999 & 28.914 & 15.727 & 0.360 & 510.590 \\
\hline dep_a & Deposits/ Total Assets & 17,986 & 75.589 & 14.806 & 0.000 & 97.821 \\
\hline dep_liab & Deposits/Total Liabilities & 17,986 & 84.165 & 16.350 & 0.000 & 101.210 \\
\hline PR & Profitability & 17,999 & 0.000 & 1.406 & -12.037 & 10.299 \\
\hline ntintmar & Net Interest Margin & 17,999 & 3.577 & 1.384 & -9.300 & 19.860 \\
\hline roa & Return on Assets & 17,999 & 0.568 & 1.221 & -9.910 & 9.590 \\
\hline roe & Return on Equity & 17,999 & 6.217 & 12.391 & -97.640 & 90.090 \\
\hline
\end{tabular}

Note that values for solvency, asset quality, profitability and liquidity can take on negative values as they were constructed using Principal Component Analysis (PCA). 
Table 8. Estimation Results for Linear Panel Estimation with Arellano-Bond and Fixed Effects for SNL Dataset

Al: Average funding cost.

\begin{tabular}{|c|c|c|c|}
\hline \multirow{2}{*}{ VARIABLES } & & \multirow{2}{*}{$\begin{array}{l}(1) \\
\mathrm{AI} \\
\end{array}$} & \multirow{2}{*}{$\begin{array}{l}(2) \\
\mathrm{AI} \\
\end{array}$} \\
\hline & & & \\
\hline \multirow[t]{2}{*}{ Solvency } & $\mathrm{SO}$ & $-0.0569 * * *$ & $-0.0858 * * *$ \\
\hline & & $(0.0060)$ & $(0.0229)$ \\
\hline \multirow[t]{2}{*}{ Asset quality } & $\mathrm{AQ}$ & -0.0059 & $0.0324 * * *$ \\
\hline & & $(0.0037)$ & $(0.0083)$ \\
\hline \multirow[t]{2}{*}{ Profitability } & $\mathrm{PR}$ & $-0.0567 * * *$ & $-0.0577 * * *$ \\
\hline & & $(0.0043)$ & $(0.0131)$ \\
\hline \multirow[t]{2}{*}{ Liquidity } & LI & $-0.0385 * * *$ & $-0.1242 * * *$ \\
\hline & & $(0.0072)$ & $(0.0259)$ \\
\hline \multirow[t]{2}{*}{ Constant } & & $3.7862 * * *$ & $4.1096 * * *$ \\
\hline & & $(0.0176)$ & $(0.0367)$ \\
\hline Observations & & 13,107 & 13,107 \\
\hline (Pseudo) R-squared & & 0.8165 & 0.4172 \\
\hline Time dummy & & $\mathrm{YES}$ & YES \\
\hline Country dummy & & $\mathrm{NO}$ & $\mathrm{NO}$ \\
\hline Bank dummy & & NO & NO \\
\hline Method & & $\mathrm{FE}$ & GMM \\
\hline Number of instruments & & $\ldots$ & 198 \\
\hline Hansen Test & & $\ldots$ & 0 \\
\hline $\mathrm{AR}(1)$ & & $\ldots$ & 0.864 \\
\hline Number of banks & & 1,975 & 1,975 \\
\hline Lags & & $\ldots$ & $1-3$ \\
\hline
\end{tabular}


Figure 1. Distribution of Wholesale Funding Cost (proxied by Interbank Funding Cost) Conditional on the Bank Solvency Measure

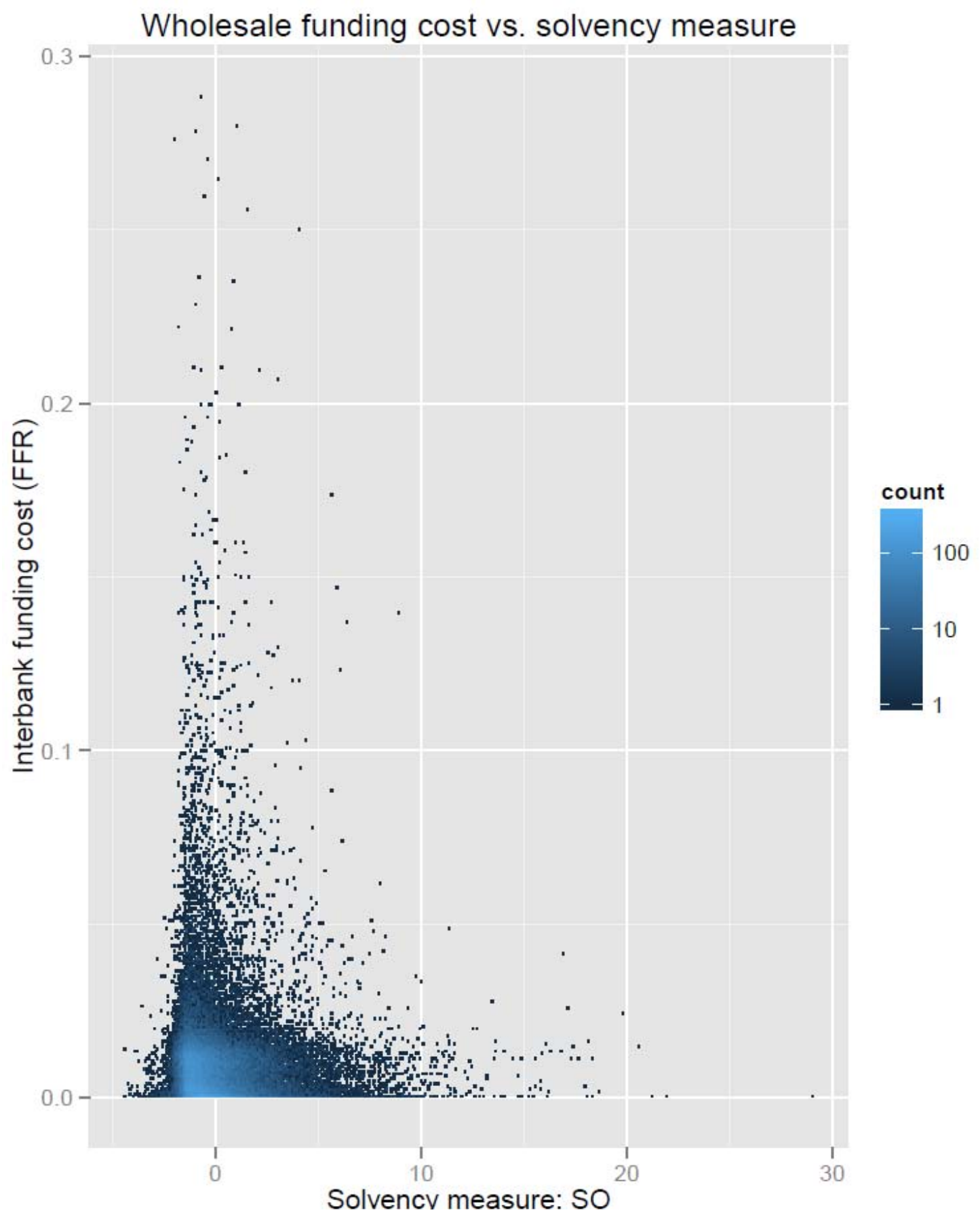


Figure 2. Estimated Coefficients of the Solvency Measure for the Linear Model over Time with Either Wholesale or Average Funding Cost as Dependent Variable

Blue triangles: Wholesale funding cost. Red circles: Average funding cost.

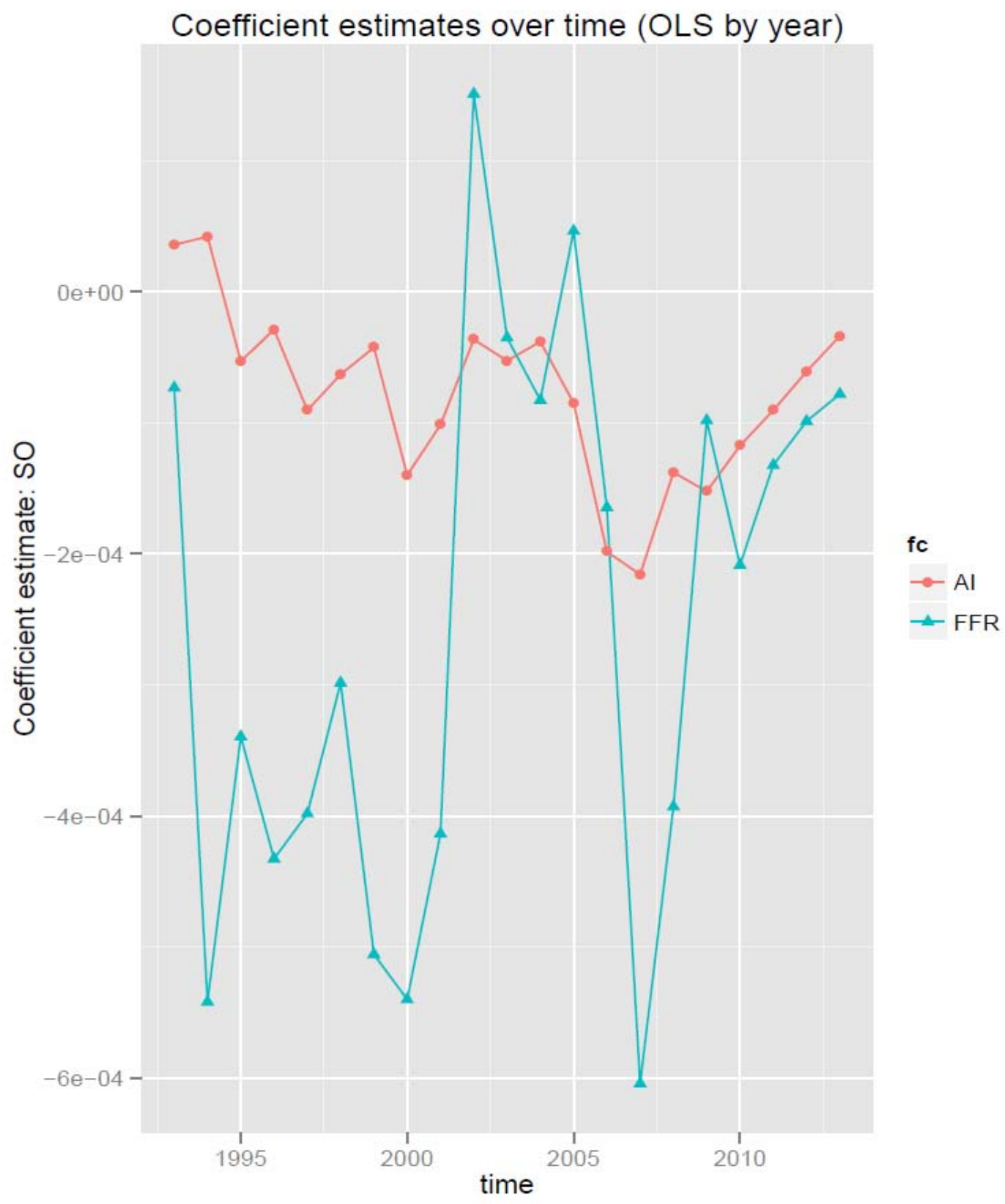


Figure 3. Estimated Coefficients and p-values of Coefficients of the Solvency Measure for the Linear Model over Time with Either Wholesale or Average Funding Cost as Dependent Variable

Blue triangles: Wholesale funding cost. Red circles: Average funding cost. Observations are labeled by the corresponding year of the estimation. Observations in the lower left quadrant both have the right sign for the coefficient and are significant at 1 percent level.

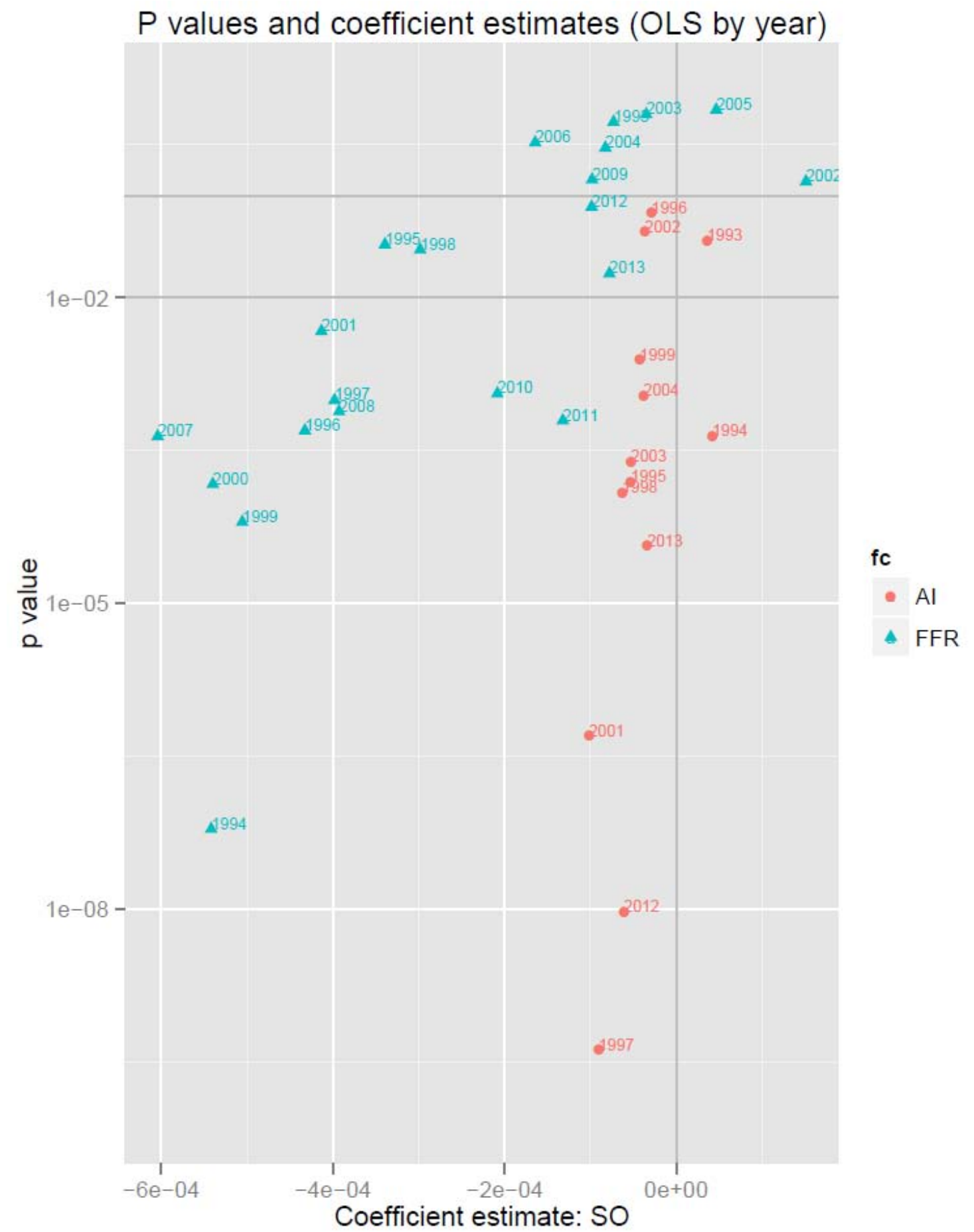

CInternational Monetary Fund. Not for Redistribution 
Figure 4. Goodness of Fit (as measured by the Pseudo R-squared) of the two parameter non-linear transformation of the solvency measure

We plot the pseudo R-squared for each pair of offset value mu and exponent $z$. For comparison we also plot the pseudo R-squared of the piecewise linear model for the highest scoring threshold parameter.

\section{Goodness of fit: nonlinear transformation}

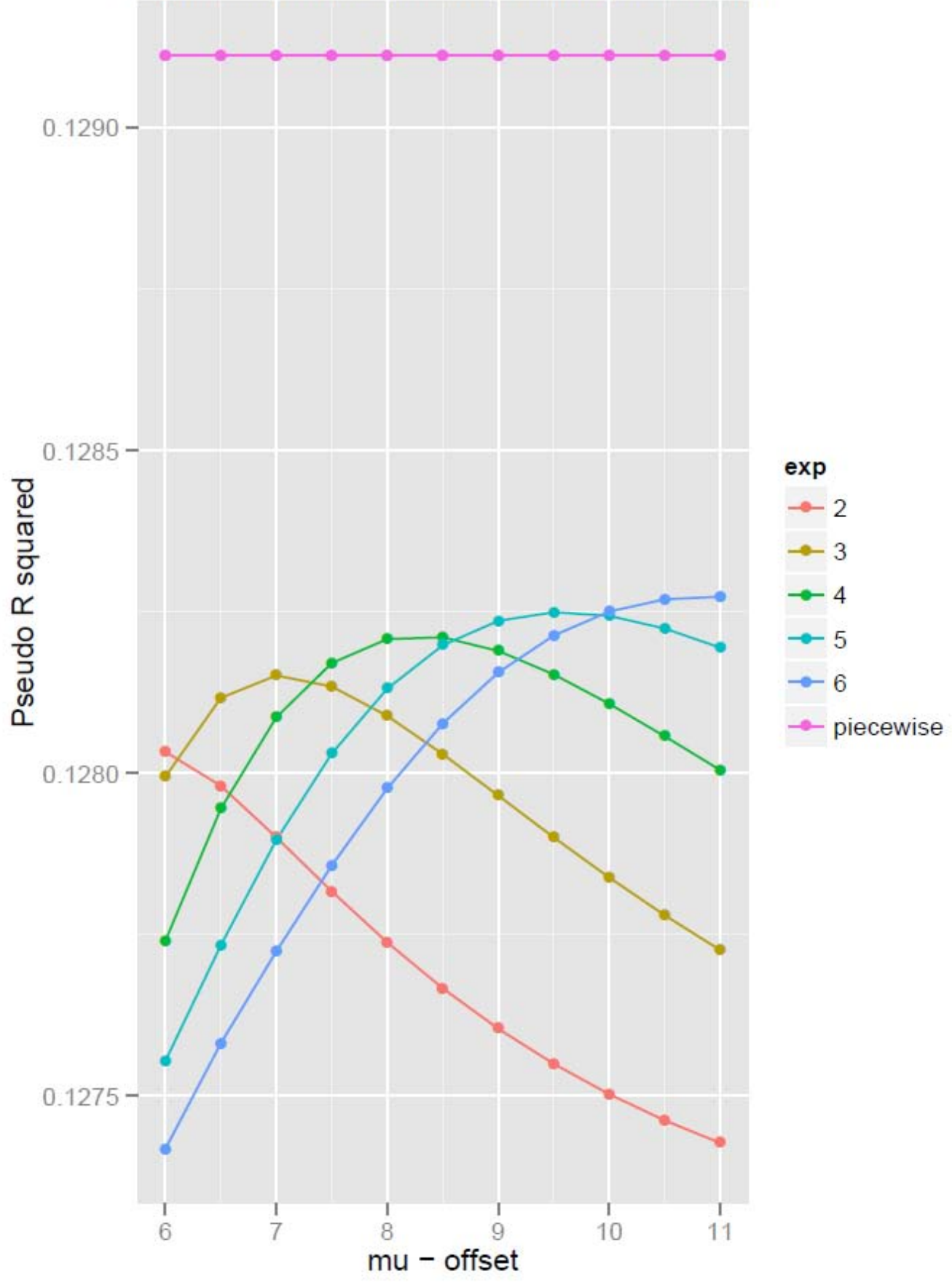




\section{REFERENCES}

Afonso, G., A. Kovner, and A. Schoar. (2011). "Stressed, not frozen: The Federal Funds Market in the Financial Crisis," The Journal of Finance, Vol. 66, pp. 1109-1139.

Arellano, M. and O. Bover. (1995). "Another look at the instrumental variable estimation of error-components models,” Journal of Econometrics, Vol. 68(1), pp. 29-51.

Aikman, D., P. Alessandri, B. Eklund, P. Gai, , S. Kapadia, E. Martin, N. Mora, G.Strene, and M.Willison. (2009). "Funding liquidity risk in a quantitative model of systemic stability,” Bank of England Working Paper No. 372.

Babihuga, R. and M. Spaltro. (2014). "Bank Funding Costs for International Banks,” IMF Working Paper, WP/14/71.

Berger, A.N. and R. Turk-Ariss. (2014). "Do Depositors Banks and Did Government Actions During the Recent Crisis Reduce this Discipline? An international Perspective," Journal of Financial Services Research, pp. 1-24.

Blundell, R. and S. Bond. (1998). "Initial conditions and moment restrictions in dynamic panel data models," Journal of Econometrics, Vol. 87, pp. 115-43.

Brunnermeier, M. and L.H. Pederson. (2009). "Market liquidity and funding liquidity," Review of Financial Studies, Vol. 22, pp. 2201-2238.

Caccioli, F., M. Shrestha, C. Moore. and J.D. Farmer. (2014). "Stability analysis of financial contagion due to overlapping portfolios," Journal of Banking and Finance, Vol. 46, pp. 233-245.

Cole, R. A. and Q. Wu. (2009). "Predicting bank failures using a simple dynamic hazard model," in 22nd Australasian Finance and Banking Conference. Sydney, Australia. December 16-18, 2009.

Gray, D. (2015). “Guidance note on bank funding cost,” IMF Technical Note.

Ioannidou, V. and J. de Dreu. (2006). “The Impact of Explicit Deposit Insurance on Market Discipline," DNB Working Paper No. 89.

Maechler, A.M. and K.M. McDill. (2006). "Dynamic depositor discipline in US banks," Journal of Banking and Finance, Vol. 30, pp. 1871-1898.

Schmieder, C., H. Hesse, B. Neudorfer, C. Puhr,. and S.W. Schmitz. (2012). "Next Generation System-Wide Liquidity Stress Testing," IMF Working Paper, WP/12/3. 